\title{
EVALUASI RENCANA KERJA SATUAN KERJA PERANGKAT DAERAHBADAN PERENCANAAN PEMBANGUNAN DAERAH KOTA \\ SEMARANG
}

R. Slamet Santoso ${ }^{1}$

Departing from the problems of weak evaluation planning at local government level work unit, we conducted this study with the aim to get an overview of the evaluation work plan on working units, and the formulation of solving the problem and provide solutions. This research was conducted with a qualitative approach, using indepth interviews and documentation of data, and then analyzed with domain analysis techniques.

The results showed evaluation work plan in Bappeda still not effective. Bappeda only to evaluate the results of the work plan at this stage, while at the policy and implementation stages have not been carried out. Some of the main problems found in the evaluation work plan Bappeda are no guidelines for internal evaluation work plan, limited information technology support, the limited number and quality planners, and not the good aspects of the legality of the work plan.

Recommendations for addressing concerns in Bappeda evaluation work plan are: strengthening the commitment of the planning; the establishment of guidelines for the evaluation of the work plan, the data developing regional planning system; to improve coordination, communication and development planning; increased monitoring of the quarter; utilization of evaluation results; and improving the quality and welfare of workers planner.

Keywords : evaluation work plan, policy, implementation, results

\section{PENDAHULUAN}

Latar Belakang Masalah. Pelaksanaan pembangunan yang terarah berdasarkan dokumen perencanaan pembangunan akan memberikan dampak lebih besar dalam upaya pencapaian tujuan dan sasaran pembangunan demi peningkatan kesejahteraan masyarakat dan kemajuan daerah.Pada era otonomi daerah pasca reformasi, pelaksanaan pembangunan daerah didasarkan pada perencanaan pembangunan yang diatur menggunakan berbagai regulasi, antara lain Undang-Undang 25 Tahun 2004 tentang Sistem Perencanaan Pembangunan Nasional, Undang-Undang Nomor 22 Tahun 1999 tentang Pemerintahan Daerah, yang telah disempurnakan dengan Undang-Undang Nomor 32 Tahun 2004 dan Undang-Undang nomor 23 Tahun 2014, kemudian telah ditetapkan regulasi operasional terkait dengan pelaksanaan teknis perencanaan pembangunan daerah, antara lain Peraturan Pemerintah Nomor 8 Tahun 2008 dan Permendagri Nomor 54 Tahun 2010.

${ }^{1}$ Staf Pengajar Program Studi S1 Administrasi Publik 
Dalam perencanaan pembangunan daerah dikenal adanya beberapa dokumen perencanaan menurut hierarki dan pentahapan tahun; pada tingkat daerah, ada Rencana Pembangunan Jangka Panjang Daerah untuk 20 tahun, Rencana Pembangunan Jangka Menengah Daerah untuk 5 tahun dan Rencana Kerja Pembangunan Daerah untuk 1 tahun; sedangkan pada tingkat unit organisasi pemerintah daerah, ada Rencana Strategis Satuan Kerja Perangkat Daerah untuk 5 tahun dan Rencana Kerja Satuan Kerja Perangkat Daerah(Renja SKPD) untuk 1 tahun.

Evaluasi terhadap pembangunan daerah sangat perlu dilakukan dalam rangka untuk melihat apakah pembangunan daerah telah mencapai tujuan/sasaran yang diharapkan dan apakah masyarakat mendapatkan manfaat dari pembangunan daerah tersebut. Evaluasi juga akan memberikan informasi penting yang berguna sebagai alat untuk membantu pemangku kepentingan dan pengambil kebijakan pembangunan dalam memahami, mengelola dan memperbaiki apa yang telah dilakukan sebelumnya.

Penyusunan, pelaksanaan dan evaluasi terhadap dokumen perencanaan pembangunan, khususnya terkait dengan dokumen Renja SKPD dirasakan masih belum maksimal. Renja SKPD adalah dokumen rencana yang memuat program dan kegiatan pada tingkat SKPD yang diperlukan untuk mencapai sasaran pembangunan, dalam bentuk kerangka regulasi dan kerangka anggaran. Beberapa fenomena di lapangan menunjukkan gejala sebagai berikut:Pertama. Penyusunan Renja SKPD masih bersifat rutin, kurang memperhatikan regulasi Permendagri Nomor 54 Tahun 2010, dimana Renja SKPD harus disusun sesuai dengan sistematika dan substansi yang telah ditentukan. Pada kenyataanya, Renja SKPD disusun setiap tahun hanya memperhatikan Renja SKPD tahun sebelumnya dengan melakukan sedikit penyesuaian dalam jenis kegiatan dan nilai anggaran, kurang memperhatikan akselerasi pencapaian dokumen lain yang lebih makro (Renstra SKPD dan RPJMD); Kedua. Pelaksanaan Renja SKPD masih belum memberikan penekanan khusus pada upaya menjaga keselarasan (sinkronisasi) antar dokumen perencanaan, baik yang berada pada tingkat SKPD maupun pada tingkat Daerah. Renja SKPD yang disusun belum memiliki keterkaitan yang optimal dengan dokumen Renstra SKPD pada tingkat SKPD, dan dokumen RPJMD pada tingkat Daerah; Ketiga. Hasil Renja SKPD belum sepenuhnya memiliki kinerja yang baik, baik dilihat dari capaian kinerja indikator makro (indikator pembangunan daerah) maupun capaian kinerja indikator mikro (indikator program dan 
kegiatan) pada setiap tahunnya; dan Keempat. Pada beberapa hal lain, masih perlu perbaikan dalam hal ketepatan dan ketersediaan dukungan data pelaporan tahunan, kualitas sumber daya manusia perencana pada unit program setiap SPKD, dukungan teknologi informasi dan komunikasi dalam sistem perencanaan pembangunan daerah, dan sebagainya.

Berdasarkan pada fenomena belum optimalnya evaluasi Renja SKPD tersebut, maka sangat perlu untuk dilakukan penelitian khusus tentang Evaluasi Renja SKPD. Lokus penelitian akan mengambil lokasi pada Badan Perencanaan Pembangunan Daerah (Bappeda) Kota Semarang, dengan pertimbangan disamping Bappeda sebagai salah satu SKPD, juga sekaligus sebagai SKPD yang memiliki kewenangan dalam pembinaan kewenangan perencanaan pembangunan di tingkat daerah.

Tujuan Penelitian. Penelitian tentang Evaluasi Renja SKPD di Bappeda Kota Semarang, dilakukan dengan tujuan untuk: Pertama. Mengidentifikasi kondisi evaluasi Renja SKPD di Bappeda Kota Semarang, tujuan penelitian ini akan dicapai menggunakan pendekatan analisis komparatif antara dokumen rencana dengan dokumen realisasi pelaksanaan Renja SKPD, dan Kedua. Merumuskan usulan peningkatan kinerja evaluasi Renja SKPD di Bappeda Kota Semarang, tujuan penelitian ini akan dicapai menggunakan pendekatan analisis identifikasi kendala pasca dilakukannya evaluasi kebijakan, evaluasi pelaksanaan dan evaluasi hasil Renja SKPD.

Kajian Teoritik. Pelaksanaan penyelenggaraan pemerintahan di berbagai negara telah memberikan banyak pembelajaran tentang pengelolaan terhadap otonomi daerah. Penyelenggaraan otonomi daerah bergerak dari penerapan kewenangan mutlak di tangan pusat (sentralisasi) hingga kewenangan yang diserahkan kepada daerah (desentralisasi). Penyelenggaraan pemerintahan lokal demikian ini sangat tergantung pada pilihan sistem pemerintahan yang digunakan, dari yang sangat otoriter hingga yang liberal.

Salah satu intervensi yang diperlukan dalam peningkatan keberhasilan otonomi daerah adalah penerapan kebijakan publik yang tepat bagi pengembangan kapasitas pemerintah daerah dan masyarakat daerah. Kondisi daerah dengan pemerintahannya cenderung berbeda-beda, ada yang sudah maju ada yang masih berkembang; kondisi ini disebabkan oleh banyak faktor, baik internal maupun eksternal. Kebijakan publik terkait otonomi daerah harus dapat menangkap perbedaan kondisi ini, untuk kemudian 
memberikan intervensi yang tepat, sehingga setiap daerah tetap dapat menikmati kemajuannya masing-masing.

Bentuk kebijakan publik yang sangat berpengaruh pada pembangunan pembangunan daerah adalah kebijakan tentang perencanaan pembangunan daerah. Pada saat ini daerah telah memiliki berbagai dokumen perencanaan pembangunan yang terintegrasi dengan perencanaan pembangunan nasional, sesuai yang di atur dalam Undang-Undang Nomor 25 Tahun 2004 tentang Sistem Perencanaan Pembangunan Nasional (SPPN). Secara teknis untuk perencanaan pembangunan di daerah telah ditetapkan regulasi operasional, antara lain Peraturan Pemerintah Nomor 8 Tahun 2008 dan Peraturan Menteri Dalam Negeri Nomor 54 Tahun 2010, kesemua aturan tersebut menegaskan pentingnya perencanaan pembangunan bagi peningkatan kesejahteraan masyarakat dan kemajuan daerah, dengan tidak meninggalkan sinergitas pembangunan nasional.

Pengetahuan tentang perencanaan akan membawa kesuksesan bagi suatu organisasi, sebagaimana disampaikan oleh Norris dan Poulton (2010: 1) bahwa Pemimpin yang sukses menggunakan strategi untuk membingkai perlunya perubahan dan mengembangkan organisasi, membangun kapasitas untuk makmur dalam dunia yang berubah dan lingkungan yang kompetitif. Kapasitas organisasi melibatkan: (1) kepemimpinan; (2) infrastruktur fasilitas, teknologi, dan peralatan; (3) penawaran program dan kapasitas pengetahuan-penemuan; (4) nilai-nilai, keterampilan, dan kompetensi administrator; (5) proses dan administrasi; dan (6) organisasi budaya.

Dalam proses perencanaan, lembaga menemukan bagaimana harus meningkatkan kapasitas organisasi dalam rangka untuk berkembang. Perencanaan akan memberikan fokus buat organisasi tentang masa depan yang akan dicapai, kemudian dengan strategi yang dirumuskan dan dieksekusi akan membuat organisasi berjalan sesuai dengan arah yang ditetapkan, menuju pada peningkatan kapasitas organisasi, baik dari sisi kepemimpinan, infrastruktur, nilai, keahlian, proses, dan budaya organisasi. Dapat disimpulkan bahwa terdapat keterkaitan yang erat antara perencanaan, pelaksanaan strategi dan peningkatan kapasitas organisasi.

Sebuah kontinum manajemen strategis memiliki tiga tahapan tujuan dasar, melalui: (1) Perencanaan strategis (efektivitas): Melakukan hal yang benar, (2) Manajemen sumber daya (efisiensi): Melakukan hal yang benar, dan (3) Kontrol dan 
evaluasi (akuntabilitas): Menjadi bertanggung jawab atas apa yang dilakukan. Manajemen strategis berkaitan dengan memutuskan terlebih dahulu apa yang harus dilakukan suatu organisasi di masa depan (perencanaan strategis), menentukan bagaimana hal itu dilakukan dan siapa yang akan melakukannya (manajemen sumber daya), kemudian melakukan monitoring dan meningkatkan kegiatan yang sedang berlangsung (kontrol dan evaluasi). Ini melibatkan efek gabungan dari tiga komponen dasar ini dalam memenuhi tujuan dan sasaran organisasi (Steiss, 2003:8).

Selanjutnya, pentingnya evaluasi dalam perencanaan disampaikan oleh Katsioloudes (2006: 223), bahwa setelah keputusan pilihan strategis yang telah dibuat, rencana strategis dirumuskan, dan strategi telah dilaksanakan, masih ada keputusan penting yang dibutuhkan untuk memastikan sukses suatu perencanaan. Sebuah evaluasi strategi dan proses pengendalian perlu dilakukan agar organisasi dapat memantau kinerja dan mengambil tindakan korektif jika diperlukan. Evaluasi dan pengendalian menjadi proses pemantauan terus menerus seluruh perumusan dan pelaksanaan tahapan perencanaan, hal ini diperlukan agar semua permasalahan dapat diatasi dengan tepat. Evaluasi strategi didefinisikan sebagai proses mengevaluasi rencana dan pemantauan kinerja organisasi sehingga kinerja aktual dapat dibandingkan dengan kinerja yang diinginkan, kemudian melakukan tindakan korektif.

Dalam evaluasi dan kontrol sebagai rangkaian manajemen strategis dikenal beberapa instrumen atau metodologi yang dapat diterapkan, sebagaimana disampaikan oleh Steiss (2003: 18) berikut ini: (1) Pengendalian dan Informasi Evaluasi Sistem Manajemen, (2) Sistem Pendukung Keputusan, (3) Akuntansi Manajerial dan Biaya, (4) Akuntansi Pertanggungjawaban, (5) Akuntansi Keuangan, (6) Sistem Pengendalian Strategis, (7) Evaluasi formatif dan Sumatif, (8) Analisis Jaringan, (9) Jadwal Rincian Kerja, (10) Heuristik, dan (11) Mekanisme Umpan Balik.Berdasarkan pendapat Steiss di atas, evaluasi perencanaan pembangunan daerah juga memiliki kesamaan instrumen atau metodologi, terutama terkait dengan penerapan sistem manajemen evaluasi perencanaan, sistem pengendalian strategis, jadwal rincian kerja dan lain-lain, yang selengkapnya telah diformulasikan menjadi berbagai regulasi terkait dengan evaluasi dan pengendalian perencanaan pembangunan daerah.

Pengendalian dan evaluasi pencapaian target kinerja pembangunan merupakan langkah strategis agar pelaksanaan program dan kegiatan setiap satuan kerja sesuai 
dengan target yang telah ditetapkan. Disamping itu langkah ini diperlukan untuk memastikan bahwa visi, misi, tujuan dan sasaran strategis di dalam RPJM (Rencana Pembangunan Jangka Menengah) dijabarkan dan dilaksanakan secara konsisten, terarah dan fokus melalui program dan kegiatan setiap Satuan Kerja.

\section{METODE PENELITIAN}

Penelitian Evaluasi Renja di Bappeda Kota Semarang dilakukan dengan desain penelitian deskriptif kualitatif yang ditujukan untuk mengungkapkan berbagai fenomena-fenomena praktik Evaluasi Renja di Bappeda Kota Semarang secara deskriptif tanpa mempertimbangkan kuantitas kemunculan fenomena, tetapi kedalaman informasi pada setiap fenomenanya.

Subyek atau fokus penelitian ini berpusat pada pengkajian kondisi pelaksanaan evaluasi Renja SKPD di Bappeda Kota Semarang, dan perumusan upaya perbaikan atau solusi yang memungkinkan untuk dilakuan; selanjutnya fokus penelitian ini dijabarkan dalam definisi konsep dan definisi operasional (fenomena) penelitian. Lokus dan situs penelitian ini dilakukan di Kota Semarang, yaitu di Bappeda Kota Semarang.

Sumber data penelitian ini berupa data primer yang diperoleh dari informan utama, yakni jajaran pimpinan dan pelaksana Renja SKPD di lingkungan Bappeda Kota Semarang dan data sekunder yang diperoleh melalui penkajian pustaka dan publikasi lainnya; menggunakan teknik koleksi atau pengumpulan datadaftar isian dan wawancara mendalam (in-depth interview).

Analisis dan interpretasi datadisajikan dengan teknik naratif dan dianalisis dengan teknik domain. Selanjutnya, untuk penentuan kategori penilaian Evaluasi Renja Bappeda Kota Semarang didasarkan pada Lampiran VII Permendagri Nomor 54 Tahun 2010, dimana terdapat lima kategori penilaian dengan skala sebagai berikut: (1) Sangat Tinggi $\geq 91 \%$; (2) Tinggi $\geq 76 \%-90 \%$; (3) Sedang $\geq 66 \%-75 \%$; (4) Rendah $\geq 51 \%$ $65 \%$; dan (5) Sangat Rendah $\leq 50 \%$.

\section{HASIL PENELITIAN}

Penelitian Evaluasi Renja SKPD dilakukan pada institusi yang berwenang dalam perencanaan pembangunan daerah di Pemerintah Kota Semarang, yaitu Bappeda. SKPD Bappeda dibentuk berdasarkan pada Peraturan Daerah Kota Semarang Nomor 13 Tahun 
2008 tentang Organisasi dan Tata Kerja Lembaga Teknis Daerah dan Badan Pelayaan Perijinan Terpadu Kota Semarang.

Evaluasi Pembangunan Daerah. Sebelum disampaikan hasil tentang Evaluasi Renja SKPD Bappeda Kota Semarang, perlu disampaikan terlebih dahulu tentang kinerja pembangunan Kota Semarang secara umum, yang ditunjukkan dengan pencapaian atas beberapa indikator pembangunan ekonomi dan sosial daerah sebagai berikut:

Pertumbuhan PDRB.Perkembangan PDRB Atas Dasar Harga Berlaku (ADHB) Kota Semarang dalam kurun waktu 4 tahun terakhir (2010-2013) mengalami peningkatan dari Rp.43.398.190,77 pada tahun 2010 menjadi sebesar Rp.61.317.000,86 pada tahun 2013. Peningkatan juga ditemukan pada PDRB Atas Dasar Harga Konstan (ADHK), yaitu dari sebesar Rp.21.365.817,80 pada tahun 2010 menjadi sebesar Rp.25.608.529,15 pada tahun 2013.

Kontribusi PDRB. Sumbangan terbesar PDRB ADHB Kota Semarang pada tahun 2013 berasal dari sektor perdagangan, hotel dan restoran yaitu 28,73\%, diikuti sektor industri pengolahan sebesar 24,66\%;sektor pertambangan dan penggalian memiliki kontribusi terkecil sebesar 0,14\%. Sedangkan dari sisi PDRB ADHK, kontribusi terbesar dari sektor perdagangan, hotel dan restoran yaitu $31,30 \%$, diikuti sektor industri pengolahan sebesar $26,36 \%$.

Petumbuhann Ekonomi. Dalam kurun waktu 3 tahun (2010-2012), pertumbuhan ekonomi Kota Semarang ADHK selalu berada di atas pertumbuhan ekonomi Provinsi Jawa Tengah, akan tetapi pada tahun 2013, pertumbuhan ekonomi Kota Semarang berada di bawah capaian pertumbuhan ekonomi Jawa Tengah yaitu sebesar 5,84\%.

Laju Inflasi. Laju inflasi Kota Semarang pada kurun waktu 4 tahun (2010-2013) mengalami peningkatan. Meskipun mengalami penurunan dari 7,11\% pada tahun 2010 menjadi sebesar 2,87 \% pada tahun 2011, laju inflasi Kota Semarang kembali mengalami kenaikan pada 2 tahun berikutnya. Inflasi pada tahun 2012 adalah sebesar 4,85\% lebih besar dari target inflasi pada tahun yang sama yaitu sebesar 3,53\% dan pada tahun 2013 menjadi sebesar $8,19 \%$ jauh lebih besar dari target inflasi yang hanya sebesar 3.36\%.

Indeks Gini. Nilai Indeks Gini Kota Semarang berada pada angka 0,32-0,4. Angka ini menunjukkan bahwa ketimpangan pendapatan di Kota Semarang termasuk dalam 
kategori sedang. Ketimpangan terbesar terjadi pada tahun 2011 dimana nilai indeks gini mencapai angka 0,3545 naik dari nilai semula yaitu sebesar 0,3224 pada tahun 2010 .

Penduduk Miskin. Penduduk miskin Kota Semarang pada tahun 2008-2012 menunjukkan tren penurunan. Pada tahun 2008, persentase penduduk miskin sebesar $6,00 \%$ turun menjadi $4,84 \%$ pada tahun 2009 . Akan tetapi, terjadi peningkatan pada tahun 2010menjadi sebesar 5,12\%, dan sebesar 5,68\% pada tahun 2011. Jika dilihat dari angka mutlak, jumlah penduduk miskin Kota Semarang pada tahun 2008 sebesar 89.617 jiwa dan pada tahun 2012 sebesar 81.900 jiwa.

Indeks Pembanguan Manusia. Perkembangan IPM Kota Semarang pada tahun 2008-2012 mengalami peningkatan sejalan dengan peningkatan IPM Provinsi Jawa Tengah. Pada tahun 2008, IPM Kota Semarang sebesar 76,54 lebih tinggi dari IPM Provinsi Jawa Tengah 71,60. Pada tahun 2012, IPM Kota Semarang sebesar 77,98 juga lebih tinggi dari IPM Provinsi Jawa Tengah. Hal ini menunjukkan bahwa tingkat kesejahteraan masyarakat di Kota Semarang jika dilihat dari 4 (empat) indikator pembentuk IPM sudah mengalami perbaikan di tiap tahunnya.

Evaluasi Renja Bappeda. Berdasarkan pada hasil pengumpulan data lapangan melalui beberapa kali pertemuan (diskusi dan wawancara) dengan informan dari Bappeda Kota Semarang, yaitu: Kabid Data dan Pelaporan, Kasubag Program, dan Staf Pengolah Data, kemudian dilengkapi dengan pengamatan dan dokumentasi, maka dapat dideskripsikan secara terstruktur sebagai berikut:

Kebijakan Perencanaanan. Pada evaluasi atas kebijakan perencanaan, dalam hal ini Renja Bappeda, ditemukan kondisi bahwa Bappeda Kota Semarang sampai saat ini belum pernah melakukan evaluasi kebijakan secara sistematis sesuai dengan ketentuan perundang-undangan yang berlaku (Permendagri Nomor 54 Tahun 2010), hasil evaluasi selengkapnya tampak pada tabel berikut:

\begin{tabular}{|c|l|l|}
\hline No. & \multicolumn{1}{|c|}{ Parameter } & \multicolumn{1}{c|}{ Temuan } \\
\hline 1. & $\begin{array}{l}\text { Pembentukan tim } \\
\text { penyusun Renja } \\
\text { SKPD }\end{array}$ & $\begin{array}{l}\text { Bappeda sudah membentuk tim khusus untuk } \\
\text { penyusun Renja Bappeda.Penyusunan Renja } \\
\text { dilakukan sebagai tupoksi dari sub bagian program } \\
\text { di Sekretariat Bappeda. }\end{array}$ \\
\hline 2. & $\begin{array}{l}\text { Pengolahan data dan } \\
\text { informasi. }\end{array}$ & $\begin{array}{l}\text { Data perencanaan disediakan melalui mekanisme } \\
\text { teknologi informasi perencanaan (SIMPERDA), } \\
\text { yang kondisinya sudah cukup baik, mampu } \\
\text { memenuhi kebutuhan pendataan perencanaaan, } \\
\text { baik tahunan maupun lima tahunan. }\end{array}$ \\
\hline
\end{tabular}




\begin{tabular}{|c|c|c|}
\hline No. & Parameter & \\
\hline 3. & $\begin{array}{l}\text { Analisis gambaran } \\
\text { pelayanan SKPD. }\end{array}$ & $\begin{array}{l}\text { Analisis yang dilakukan terkait dengan apakah } \\
\text { tupoksi Bappeda sudah dijalankan dengan baik, } \\
\text { parameternya adalah urusan dan SPM yang diampu } \\
\text { oleh Bappeda, dukungan sumber daya, dan lain- } \\
\text { lain. }\end{array}$ \\
\hline 4. & $\begin{array}{l}\text { Mengkaji hasil } \\
\text { evaluasi renja-SKPD } \\
\text { tahun lalu } \\
\text { berdasarkan renstra- } \\
\text { SKPD. }\end{array}$ & $\begin{array}{l}\text { Penyiapan Renja Bappeda sudah didukung dengan } \\
\text { hasil evaluasi Renja tahun sebelumnya. Evaluasi } \\
\text { yang dilakukan hanya berupa evaluasi hasil Renja, } \\
\text { yaitu terkait dengan indikator kinerja outcome } \\
\text { (program) dan output (kegiatan). }\end{array}$ \\
\hline 5. & $\begin{array}{l}\text { Penentuan isu-isu } \\
\text { penting } \\
\text { penyelenggaraan } \\
\text { tugas dan fungsi } \\
\text { SKPD. }\end{array}$ & $\begin{array}{l}\text { Penyusunan isu strategis dalam Renja dilakukan } \\
\text { oleh Sekretariat Bappeda.Isu strategis Bappeda } \\
\text { dirumuskan dari hasil evaluasi Renja tahun } \\
\text { sebelumnya, juga dikaitkan dengan isu-isu yang } \\
\text { akan diprioritaskan penangannannya pada tahun } \\
\text { yang akan datang yang diperoleh melalui berbagai } \\
\text { rujukan atau arahan, misalnya dari RKP, RKPD } \\
\text { Provinsi, dan lain-lain. }\end{array}$ \\
\hline 6. & $\begin{array}{l}\text { Penelaahan } \\
\text { rancangan awal } \\
\text { RKPD. }\end{array}$ & $\begin{array}{l}\text { Penyusunan Renja sangat terkait dengan } \\
\text { penyusunan RKPD, sehingga arahan dari } \\
\text { rancangan awal RKPD sangat diperhatikan dalam } \\
\text { penyusunan Renja. }\end{array}$ \\
\hline 7. & $\begin{array}{l}\text { Perur } \\
\text { dan } \mathrm{s}\end{array}$ & $\begin{array}{l}\text { Penyusunan tujuan dan sasaran Renja sudah } \\
\text { dilakukan dengan mengkaitkan pada isu dan } \\
\text { prioritas apa yang akan ditangani dan ditekankan } \\
\text { pada tahun perencanaan. }\end{array}$ \\
\hline 8. & $\begin{array}{l}\text { Penelaahan usulan } \\
\text { masyarakat. }\end{array}$ & $\begin{array}{l}\text { Usulan masyarakat dilakukan melalui forum } \\
\text { Musrenbang, sejak tingkat Kelurahan, Kecamatan, } \\
\text { SKPD, hingga Kota.Usulan masyarakat dikaji oleh } \\
\text { SKPD disesuaikan dengan prioritas tahunan yang } \\
\text { akan dicanangkan dalam RKPD, juga dikaitkan } \\
\text { dengan ketersediaan alokasi anggaran. }\end{array}$ \\
\hline 9. & $\begin{array}{l}\text { Perumusan kegiatan } \\
\text { prioritas. }\end{array}$ & $\begin{array}{l}\text { Penyusunan prioritas pada Renja Bappeda lebih } \\
\text { didasarkan pada apa yang menjadi prioritas dalam } \\
\text { RKPD, sehingga Renja tinggal menyesuaikan. }\end{array}$ \\
\hline 10. & $\begin{array}{l}\text { Pelaksanaan forum } \\
\text { SKPD }\end{array}$ & $\begin{array}{l}\text { Dilakukan untuk mengakomodir usulan Kecamatan } \\
\text { dan SKPD, sejauhmana keselarasan dan } \\
\text { konsistensinya dilihat dari sisi kewenangan SKPD. }\end{array}$ \\
\hline 11. & $\begin{array}{l}\text { Sasaran program dan } \\
\text { kegiatan SKPD } \\
\text { disusun berdasarkan } \\
\text { pendekatan kinerja }\end{array}$ & $\begin{array}{l}\text { Penyusunan program dan kegiatan SKPD masih } \\
\text { belum didasarkan pada prinsip kinerja, karena } \\
\text { belum adanya analisis standar biaya atau belanja } \\
\text { (ASB). }\end{array}$ \\
\hline 12. & $\begin{array}{l}\text { Program dan } \\
\text { kegiatan telah } \\
\text { dibahas dalam forum } \\
\text { SKPD. }\end{array}$ & $\begin{array}{l}\text { Sudah dilakukan dalam Forum SKPD, ada proses } \\
\text { integrasi program dan SKPD; juga dilakukan } \\
\text { kembali pada tingkat Musrenbang Kota. }\end{array}$ \\
\hline 13. & Pendanaan program & Penyusunan Renstra dikaitkan dengan RPJMD, \\
\hline
\end{tabular}




\begin{tabular}{|c|l|l|}
\hline No. & \multicolumn{1}{|c|}{ Parameter } & \multicolumn{1}{c|}{ Temuan } \\
\hline $\begin{array}{l}\text { dan kegiatan } \\
\text { prioritas berdasarkan } \\
\text { pagu indikatif }\end{array}$ & $\begin{array}{l}\text { namun pada tingkat Renja sudah tidak lagi bisa } \\
\text { dikaitkan dengan Renstra.Kondisi demikian akan } \\
\text { sulit dalam melakukan evaluasi, karena dipastikan } \\
\text { akan tidak sesuai antara Renja dengan Renstra. }\end{array}$ \\
\hline 14. & $\begin{array}{l}\text { Dokumen Renja } \\
\text { SKPD dilaporkan } \\
\text { Kepala SKPD } \\
\text { kepada Kepala } \\
\text { Bappeda. }\end{array}$ & $\begin{array}{l}\text { Rancangan Renja SKPD tidak pernah diverifikasi } \\
\text { Bappeda; karena Bappeda melepaskan penyusunan } \\
\text { Renja pada SKPD masing-masing.Bappeda tidak } \\
\text { mengeluarkan arahan kebijakan utuh untuk } \\
\text { memandu SKPD lain dalam penyusunan Renja dari } \\
\text { awal hingga pengesahan. }\end{array}$ \\
\hline 15. & $\begin{array}{l}\text { Kepala Bappeda } \\
\text { melakukan } \\
\text { verifikasisinkronisasi } \\
\text { Renja SKPD dengan } \\
\text { RKPD. }\end{array}$ & $\begin{array}{l}\text { Penyusunan Renja diintegrasikan dalam tahapan } \\
\text { penyusunan rancangan awal RKPD.Bappeda } \\
\text { melakukan verifikasi, terutama dalam penentuan } \\
\text { prioritas pembangunan tahun yang akan } \\
\text { direncanakan dalam Renja sudah selaras atau } \\
\text { sinkron dengan RKPD. }\end{array}$ \\
\hline 16. & $\begin{array}{l}\text { Kepala Bappeda } \\
\text { menghimpun seluruh } \\
\text { rancangan akhir } \\
\text { Renja SKPD }\end{array}$ & $\begin{array}{l}\text { Tahapan ini masih tidak maksimal, artinya Bappeda } \\
\text { belum melakukan penghimpunan terhadap seluruh } \\
\text { rancangan akhir Renja SKPD, kondisi senyatanya } \\
\text { tergantung pada kesadaran SKPD untuk } \\
\text { menyerahkan rancangan akhir ke Bappeda atau } \\
\text { tidak. }\end{array}$ \\
\hline
\end{tabular}

Sumber: Hasil Wawancara, 2015.

Pelaksanaan Perencanaan. Evaluasi pelaksanaan Renja sesuai dengan ketentuan yang berlaku (Permendagri Nomor 54 Tahun 2010) belum pernah dilakukan oleh Bappeda secara sistematis. Evaluasi pelaksanaan yang dilakukan hanya terbatas pada mencari "arsiran" atau kesamaan dari perencanaan tahunan dengan perencanaan lima tahunan, atau perencanaan tahunan daerah dengan perencanaan tahunan SKPD, hasil evaluasi selengkapnya tampak pada tabel berikut:

\begin{tabular}{|c|l|l|}
\hline No. & \multicolumn{1}{|c|}{ Parameter } & \multicolumn{1}{c|}{ Temuan } \\
\hline 1. & $\begin{array}{l}\text { Sinkronisasi urusan, } \\
\text { program dan } \\
\text { kegiatan dalam } \\
\text { dokumen }\end{array}$ & $\begin{array}{l}\text { Bappeda Kota Semarang telah melakukan langkah } \\
\text { sinkronisasi Renja dengan berbagai dokumen } \\
\text { perencanaan dan penganggaran, seperti Renstra } \\
\text { Bappeda dan RKA Bappeda, telah } \\
\text { dioprasionalisasikan dalam dokumen perencanaan } \\
\text { jangka pendek (Renja).Sinkronisasi agak sulit } \\
\text { dikawal pada tingkat ketepatan perencanaan } \\
\text { anggaran, artinya pagu anggaran lima tahunan akan } \\
\text { sulit dikawal dalam pagu anggaran tahunan. } \\
\text { Namun, sering terjadi adanya penambahan/ } \\
\text { perubahan karena adanya perubahan prioritas } \\
\text { daerah. }\end{array}$ \\
\hline 2. & Sinkronisasi & Sinkronisasi indikator juga sudah dilakukan, baik \\
\hline
\end{tabular}




\begin{tabular}{|c|l|l|}
\hline No. & \multicolumn{1}{|c|}{ Parameter } & \multicolumn{1}{c|}{ Temuan } \\
\hline & $\begin{array}{l}\text { indikator kinerja } \\
\text { dalam dokumen }\end{array}$ & $\begin{array}{l}\text { pada tingkat makro (indikator kinerja level kota), } \\
\text { maupun tingkat mikro (indikator kinerja level } \\
\text { SKPD).Indikator level kota lebih diperhatikan } \\
\text { karena menjadi penentu kinerja pembangunan kota. } \\
\text { Indikator level SKPD, cenderung lebih banyak, dan } \\
\text { rinci, sering berubah disesuaikan dengan kebutuhan } \\
\text { yang ada. }\end{array}$ \\
\hline 3. & $\begin{array}{l}\text { Sinkronisasi lokasi } \\
\text { program dan } \\
\text { kegiatan }\end{array}$ & $\begin{array}{l}\text { Sinkronisasi lokasi program bagian yang sulit } \\
\text { dilakukan antara dokumen Renstra dengan } \\
\text { dokumen tahunan (Renja dan RKA).Lokasi } \\
\text { program dan kegiatan pada Renstra belum } \\
\text { tersebutkan, lokasi baru akan muncul pada } \\
\text { dokumen Renja dan RKA. }\end{array}$ \\
\hline 4. & $\begin{array}{l}\text { Sinkronisasi target } \\
\text { capaian program } \\
\text { dan kegiatan dalam } \\
\text { dokumen }\end{array}$ & $\begin{array}{l}\text { Kondisi sinkronisasi target capaian (kinerja) hampir } \\
\text { sama uraiannya dengan nomor 2. Indikator kinerja } \\
\text { menetapkan rumusan parameternya saja, sedangkan } \\
\text { pada nomor 4 ini menetapkan besaran nilai yang } \\
\text { akan dicapai secara kuantitatif (target } \\
\text { kinerja).Target kinerja pada level kota cenderung } \\
\text { lebih sinkron dibandingkan level SKPD dalam } \\
\text { pengawalannya. }\end{array}$ \\
\hline 5. & $\begin{array}{l}\text { Sinkronisasi dana/ } \\
\text { anggaran program } \\
\text { dan kegiatan dalam } \\
\text { dokumen } \\
\text { belum bisa berjalan dengan baik karena selama ini } \\
\text { Bappeda belum menerapkan analisis standar } \\
\text { biaya/belanja.Pada level Renstra belum dapat } \\
\text { diketahui alokasi anggaran SKPD sampai } \\
\text { detail/rinci, sehingga biasanya pada tahapan } \\
\text { penyusunan Renja, alokasi anggaran baru akan } \\
\text { diperinci sesuai dengan kebutuhan riil yang harus } \\
\text { ditangani. }\end{array}$ \\
\hline
\end{tabular}

Sumber: Hasil Wawancara, 2015.

Hasil Perencanaanan. Selama ini yang menjadi prioritas utama Bappeda dalam evaluasi Renja adalah pada tahapan evaluasi hasil perencanaan. Evaluasi hasil yang dilaksanakan telah memenuhi ketentuan Permendagri Nomor 54 Tahun 2010, dan hasilnya menjadi dasar dalam penyusunan perencanaan pada tahun berikutnya, hasil evaluasi selengkapnya tampak pada tabel berikut:

\begin{tabular}{|c|l|l|}
\hline No. & \multicolumn{1}{|c|}{ Parameter } & \multicolumn{1}{c|}{ Temuan } \\
\hline 1. & Target kinerja dan & Telah dilakukan evaluasi hasil yang \\
& anggaran program & membandingkan target kinerja dan anggaran antara \\
& dan kegiatan pada & dokumen Renja Bappeda dengan dokumen Renstra \\
& akhir Renstra & Bappeda.Matriks evaluasi sesuai ketentuan \\
& dibandingkan & dimodifikasi sesuai dengan kebutuhan dan \\
& dengan realisasi & ketersediaan data, yang diarahkan pada evaluasi \\
& capaian target & kinerja dan anggaran serta kesesuaian.Kesesuaian \\
\hline
\end{tabular}




\begin{tabular}{|c|c|c|}
\hline No. & Parameter & Temuan \\
\hline & $\begin{array}{l}\text { kinerja dan } \\
\text { anggaran program } \\
\text { dan kegiatan tahun } \\
\text { berkenaan }\end{array}$ & $\begin{array}{l}\text { digunakan untuk melihat irisan antara dokumen } \\
\text { perencanaan tahunan dengan dokumen perencanaan } \\
\text { lima tahunan. Hasil dari evaluasi ini dapat dilihat } \\
\text { pada Tabel 3.4. }\end{array}$ \\
\hline 2. & $\begin{array}{l}\text { Target kinerja dan } \\
\text { anggaran program } \\
\text { dan kegiatan pada } \\
\text { tahun berkenaan } \\
\text { dibandingkan } \\
\text { dengan realisasi } \\
\text { capaian target } \\
\text { kinerja dan } \\
\text { anggaran program } \\
\text { dan kegiatan tahun } \\
\text { berkenaan }\end{array}$ & $\begin{array}{l}\text { Telah dilakukan evaluasi hasil yang } \\
\text { membandingkan target kinerja dan anggaran Renja } \\
\text { (awal tahun) dengan realisasinya pada akhir } \\
\text { tahun.Matriks evaluasi sesuai ketentuan } \\
\text { dimodifikasi sesuai dengan kebutuhan dan } \\
\text { ketersediaan data, yang diarahkan pada evaluasi } \\
\text { kinerja dan anggaran serta kesesuaian. } \\
\text { Ada evaluasi per triwulan, jadi satu tahun ada } 4 \\
\text { evaluasi triwulan, digunakan untuk mengetahui } \\
\text { progress capaian program dan kegiatan, sekaligus } \\
\text { digunakan untuk fungsi pengendalian agar target } \\
\text { dapat tercapai sesuai dengan yang direncanakan. }\end{array}$ \\
\hline 3. & $\begin{array}{l}\text { Bentuk } \\
\text { permasalahan yang } \\
\text { dihadapi dalam } \\
\text { pelaksanaan } \\
\text { program dan } \\
\text { kegiatan tahunan. }\end{array}$ & $\begin{array}{l}\text { Pada evaluasi hasil Renja dikaitkan dengan Renstra, } \\
\text { permasalahan utama yang ditemukan adalah } \\
\text { banyaknya target lima tahunan yang tidak sinkron } \\
\text { dengan target tahunan; target tahunan akan } \\
\text { berkembang lebih besar/ banyak.Pada evaluasi hasil } \\
\text { Renja, untuk target dan realisasi pada tahun } \\
\text { berkenaan, permasalahan yang muncul adalah } \\
\text { munculnya tambahan kegiatan baru yang cenderung } \\
\text { tidak pernah direncanakan; lemahnya pemantauan } \\
\text { perkembangan data realisasi baik kinerja maupun } \\
\text { anggaran (ada yang masih kosong, padahal sudah } \\
\text { selesai tahun anggarannya). }\end{array}$ \\
\hline 4. & $\begin{array}{l}\text { Bentuk penanganan } \\
\text { permasalahan yang } \\
\text { dihadapi dalam } \\
\text { pelaksanaan } \\
\text { program dan } \\
\text { kegiatan tahunan. }\end{array}$ & $\begin{array}{l}\text { Penanganan yang diambil adalah pemantauan target } \\
\text { Renstra, karena sangat terkait dengan target } \\
\text { RPJMD, melalui pelaksanaan evaluasi Renstra dan } \\
\text { evaluasi RPJMD secara periodik.Penanganan pada } \\
\text { tingkat tahunan, dilakukan upaya perbaikan } \\
\text { penentuan besaran kinerja, baik anggaran maupun } \\
\text { non anggaran, dengan mulai mengembangkan } \\
\text { analisis standar biaya/belanja; penekanan pada } \\
\text { komitemen lintas sektor untuk menjaga konsistensi } \\
\text { pelaksanaan rencana yang telah ditetapkan. }\end{array}$ \\
\hline 5. & $\begin{array}{l}\text { Efektivitas hasil } \\
\text { penanganan } \\
\text { permasalahan yang } \\
\text { dihadapi dalam } \\
\text { pelaksanaan } \\
\text { program dan } \\
\text { kegiatan tahunan. }\end{array}$ & $\begin{array}{l}\text { Pelaksanaan penanganan permasalahan masih } \\
\text { belum dapat optimal karena program ASB masih } \\
\text { belum selesai, dan pada sisi lain, belum berkembang } \\
\text { komitmen yang kuat untuk mengawal dokumen } \\
\text { perencanaan hingga tahapan realiasi. }\end{array}$ \\
\hline
\end{tabular}

Sumber: Hasil Wawancara, 2015. 
Untuk mendukung data temuan di atas, khususnya pada evaluasi hasil perencanaan, dapat disampaikan hasil analisisketerkaitan Renja dengan Renstra, yaitu: (1) Terdapat cukup banyak kegiatan baru yang muncul tanpa sumber dari Renstra, tampak dari banyaknya kegiatan tanpa target awal, akibatnya tidak bisa dibandingkan antara target dengan realisasi; (2) Terdapat kinerja penilaian kegiatan yang memang tidak mencapai hasil yang baik, baik pada sisi kinerja maupun sisi anggaran; dan (3) Hasil umum menunjukan, kinerja mencapai nilai 47,78\% atau masuk kategori sangat rendah, demikian pula untuk anggaran mencapai nilai 23,57\% atau masuk kategori sangat rendah.

Selanjutnya, atas hasil analisis capaian Renja Tahun 2013, dapat diketahui bahwa: (1) Hasil evaluasi Renja lebih baik kondisinya dibandingkan dengan evaluasi Renja dilihat dari capaian Renstra, dimana untuk capaian kinerja mencapai nilai 57,34\% atau masuk kategori rendah, demikian pula untuk capaian anggaran mencapai nilai 59,56\% atau masuk kategori rendah; dan (2) Untuk kegiatan dengan data tidak lengkap, cenderung pada data target kinerja, sedangkan data target anggaran sudah ditetapkan; ini masih menjadi pola dalam perencanaan di tingkat SKPD.

Kendala Evaluasi Renja. Evaluasi Renja masih belum menjadi kebiasaan yang dilakukan oleh Bappeda dan SKPD pada umunya, padahal harus dilaksanakan secara kontinyu sesuai amanat Permendagri Nomor 54 Tahun 2010, yang diatur lebih detail dalam Lampiran VII. Berikut ini selengkapnya akan disampaikan inventarisasi atas berbagai kendala yang ditemukan dalam evaluasi Renja, baik pada tahapan kebijakan, pelaksanaan, maupun hasil.

Kebijakan Perencanaanan. Berdasarkan pada hasil temuan dapat diinventarisasi beberapa permasalahan yang dihadapi Bappeda Kota Semarang dalam evaluasi kebijakan Renja, antara lain: (a) Bappeda tidak memberikan arahan khusus tentang evaluasi Renja kepada semua SKPD di lingkungan Pemkot Semarang; (b) Evaluasi Renja SKPD biasanya dipandang sebagai sub kegiatan dari penyusunan RKPD Kota Semarang; (c) Penyusunan evaluasi Renja diserahkan sebagai tupoksi Subbagian Program pada masing-masing Sekretariat atau Tata Usaha SKPD, ada kecenderungan lempar tanggung jawab; (d) Data informasi penyusunan evaluasi Renja masih belum optimal, baik dari sisi dukungan teknologi informasi, kemampuan SDM, integrasi sistem, maupun kerjasama lintas sektor dengan instansi vertikal pengampu data (BPS 
Kota Semarang); (e) Pelayanan Bappeda masih banyak dibebani dengan tugas-tugas yang tidak selaras dengan peran Bappeda sebagai SKPD perumus kebijakan, Bappeda masih banyak terlibat pada peran eksekusi kebijakan; (f) Bappeda sudah melakukan evaluasi Renja dari sisi hasil, namun masih belum melakukan evaluasi dari sisi kebijakan dan dari sisi pelaksanaan; (g) Penentuan isu strategis, tujuan dan sasaran masih belum sinkron dengan hasil evaluasi yang diperoleh, lebih banyak mengutamakan isu yang sudah given dari dokumen RKPD ataupun dari tingkat nasional dan provinsi; (h) Prioritas pembangunan ditentukan dari tingkat kota, pihak SKPD tinggal melakukan tindak lanjut saja; (i) Bappeda belum memiliki analisis standar biaya/ belanja, sehingga belum dapat ditentukan "pagu" realistis yang seragam untuk penentuan pembiayaan/belanja kegiatan/program yang memiliki kemiripan; (j) Penganggaran Renja tidak selaras dengan penganggaran perkiraan maju (Renstra); dan (k) Dokumen Renja belum memenuhi kelengkapan administrasi dalam pengesahan hingga tingkat Walikota.

Pelaksanaan Perencanaan. Berdasarkan pada hasil temuan dapat diinventarisasi beberapa permasalahan yang dihadapi Bappeda Kota Semarang dalam evaluasi pelaksanaan Renja, antara lain: (a) Sinkronisasi Renstra dengan Renja belum dapat berjalan dengan baik, terutama dalam menjaga konsistensi usulan kegiatan, baik dari sisi besaran kinerja maupun anggaran; (b) Indikator kinerja yang dikawal lebih pada tingkat kota yang bersifat makro, sedangkan indikator level SKPD yang bersifat mikro agak terabaikan; (c) Penentuan lokasi kegiatan cenderung tidak bisa ditetapkan jauhjauh hari, karena menyesuaikan dengan kondisi yang terjadi; dan (d) Penentuan anggaran tidak bisa diterapkan untuk jangka panjang/menengah, karena cenderung mudah berubah-ubah.

Hasil Perencanaanan. Berdasarkan pada hasil temuan dapat diinventarisasi beberapa permasalahan yang dihadapi Bappeda Kota Semarang dalam evaluasi hasil pelaksanaan Renja, antara lain: (a) Penyusunan evaluasi hasil masih terkendala dengan kesigapan dalam memberikan input perkembangan per triwulan; (b) Banyak target lima tahunan yang tidak bisa dikawal pada tingkat realisasi tahunan; dan (c) Kurangnya komitmen dalam membuat konsistensi antara penyusunan perencanaan, pelaksanaan perencanaan, dan minitoring evaluasi perencanaan.

\section{PEMBAHASAN HASIL PENELITIAN}




\section{Analisis Evaluatif Kinerja Renja}

Berdasarkan pada Peraturan Pemerintah Nomor 8 Tahun 2008, pada Pasal 46, disebutkan bahwa ruang lingkup evaluasi meliputi evaluasi: kebijakan perencanaan pembangunan daerah; pelaksanaan rencana pembangunan daerah; dan hasil rencana pembangunan daerah. PP ini dioperasionalkan melalui Permendagri Nomor 54 Tahun 2010, yaitu pada Lampiran VII yang mengatur tentang Pengendalian dan Evaluasi Perencanaan Pembangunan Daerah. Jadi, semua dokumen perencanaan pembangunan daerah, harus disertai dengan pelaksanaan evaluasi secara komprehensif meliputi evaluasi kebijakan, evaluasi pelaksanaan, dan evaluasi hasil.

Pentingnya tahapan evaluasi disampaikan oleh Franco Archibugi (2008: 46) dalam ungkapan yang bersifat paradoksal sebagai berikut: studi perencanaan dan evaluasi merupakan komplementer - "Tidak ada perencanaan tanpa evaluasi, tetapi tidak ada evaluasi tanpa perencanaan”. Dapat disimpulkan bahwa antara perencanaan dan evalusi saling melengkapi, sehingga keduanya harus dilaksanakan dengan konsisten dan berimbang, tidak boleh lebih penting satu dari yang lain.Dalam pelaksanaan evaluasi Renja pun diharapkan diposisikan sebagai suatu yang "wajib" dijalankan oleh setiap SKPD, tentunya ditujukan disamping sebagi sarana monitoring juga digunakan sebagai sarana untuk memberikan masukan pagi perbaikan kinerja perencanaan pada tahapan berikutnya.

Evaluasi Renja Bappeda Kota Semarang dikaitkan dengan parameter dalam regulasi Permendagri Nomor 54 Tahun 2010, baru memenuhi 1 (satu) dari 3 (tiga) jenis evaluasi yang harus dilakukan, yaitu jenis evaluasi pada tahapan akhir saja(hasil), sedangkan dua yang lain, yaitu evaluasi pada tahapan awal perencanaan (kebijakan) dan evaluasi pada tahapan tengah (pelaksanaan)belum dilakukan hingga saat ini.

Evaluasi Kebijakan. Pembahasan kondisi evaluasi kebijakan Renja pada Bappeda Kota Semarang dapat dilakukan secara ringkas sebagai berikut:

- Pada tahapan persiapan, dalam hal ini meliputi pembentukan tim penyusun dan pengolahan data, Bappeda Kota Semarang telah memenuhi amanah regulasi, dimana sudah ditetapkan Tim PenyusunRenja Bappeda dengan menggunakan SK Kepala Bappeda. Kemudian, dalam pelaksanaannya memang sangat terkait dengan kondisi organisasi, dimana akhirnya penyusunan Renja akhir disusun lebih banyak oleh tenaga dari Subbagian Program di Sekretariat Bappeda daripada 
melibatkan semua komponen yang terdapat dalam Tim Penyusun. Pentingnya ada tim dalam penyusunan dokumen perencanaan ditegaskan oleh John M. Bryson (2004: 35), bahwa “... Beberapa orang atau kelompok harus memulai proses. Salah satu tugas inisiatoradalah mengidentifikasi persis siapa pengambil keputusan kunci. Selanjutnya, untuk mengidentifikasi orang-orang, kelompok, unit, atau organisasi harus terlibat dalam upaya penyusunan ...”. Pernyataan tersebut menegaskan bahwa penyusunan rencana merupakan kerja tim, bukan kerja individual, dalam rangka mendapatkan hasil yang strategis dan komprehensif bagi penanganan permasalahan organisasi. Pengolahan data juga sudah dilakukan Bappeda dengan baik, namun masih terkendala pada keterbatasan sistem yang dipakai, terutama dari sisi kapasitas dan integrasi, disamping skill dan disiplin petugas yang masih kurang untuk terus mengawal perkembangan data yang ada. Keterbatasan ini mempengaruhi tim penyusun dalam mengumpulkan data pendukung yang dibutuhkan.

- $\quad$ Pada tahapan pelaksanaan, bagian ini yang paling banyak kegiatannya, antara lain: menganalisis kinerja organisasi; perumusan isu strategis, tujuan dan sasaran; penelaahan usulan masyarakat (hasil musrenbang); perumusan prioritas; dan perumusan program kegiatan beserta anggaran. Pekerjaan pelaksanaan paling menyita waktu, pikiran, tenaga dan perhatian dalam penyusunan Renja. Pekerjaan penyusunan perencanaan membutuhkan orang dengan kemampuan berpikir yang memadai, selaras dengan tujuannya untuk memperikan perubahan dan pencapaian tujuan organisasi. Bappeda telah melakukan penilaian kinerja pelayanan dan evaluasi Renja dengan cukup baik, namun masih bersifat parsial karena belum melakukan sepenuhnya sesuai dengan amanat Peremnedagri Nomor 54 Tahun 2010. Tupoksi Bappeda banyak ditambah dengan tugas lain yang bersifat teknis pelaksanaan program. Evaluasi kinerja masih sebatas pada penilaian hasil. Selanjutnya pada tahapan penyusunan isu strategis, Bappeda cenderung menerapkan asas keterkaitan dengan isu strategis daerah, provinsi dan pusat (keselarasan), sehingga kurang memanfaatkan hasil evaluasi Renja yang telah dilakukan. akibatnya perumusan tujuan, sasaran, hingga penentuan prioritas program dan kegiatanpun diarahkan untuk selaras dengan kepentingan Kota. Padahal isu strategis menurut Bryson (2004: 42) bahwa “.. isu strategis adalah 
pertanyaan mendasar kebijakan atau tantangan penting yang mempengaruhi organisasi mandat, misi dan nilai-nilai, produk atau layanan tingkat dan campuran, klien, pengguna atau pembayar, biaya, pembiayaan, struktur, proses, dan manajemen ...". Artinya, salah atau kurang tepat dalam perumusan isu strategis akan berdampak sangat luas dalam upaya pencapaian visi dan misi organisasi.

- $\quad$ Pada tahapan penetapan, bagian ini terdiri atas pengesahan secara berjenjang pada tingkat SKPD, Kepala Bappeda dan Walikota. Dalam sisi birokrasi, aspek legalitas dokumen perencanaan menjadi sangat penting, karena dijadikan dasar dalam pelaksanaan berbagai program dan kegiatan yang sah didanai dengan sumber daya milik negara. Permasalahan penetapan Renja ternyata belum memiliki keseragaman pola, Renja hanya sebatas berhenti sebagai dokumen SKPD tanpa mendapatkan pengesahan secara berjenjang dari tingat Kepala SKPD, Kepala Bappeda hingga Walikota.

Evaluasi Pelaksanaan. Pembahasan kondisi evaluasi pelaksanaan Renja pada Bappeda Kota Semarang dapat dilakukan secara ringkas sebagai berikut:

- $\quad$ Berdasarkan pada regulasi Permendagri Nomor 54 Tahun 2010, ditekankan bahwa evaluasi pelaksanaan untuk menjamin adanya keselarasan antara dokumen perencanaan, artinya Renja harus selaras, paling tidak dengan dokumen Renstra untuk tahun yang direncanakan, dan harus selaras pula dari target pada awal penyusunan Renja bila dibandingkan dengan realisasinya.

- Dalam temuan hasil penelitian, diketahui bahwa Renja Bappeda cenderung memiliki tingkat keselarasan yang kurang dilihat dari Renstra, artinya banyak terjadi penambahan program dan kegiatan di luar Renstra, dibuktikan dengan banyak yang muncul di realisasi tanpa ada awalan di Renstra, sehingga sangat sulit untuk dapat dievaluasi. Pada sisi lain, bila dilihat dari target awal Renja dibandingkan dengan realisasi Renja, cenderung sudah lebih baik.

Evaluasi Hasil. Pembahasan kondisi evaluasi hasil Renja pada Bappeda Kota Semarang dapat dilakukan secara ringkas sebagai berikut:

- $\quad$ Evaluasi hasil merupakan evaluasi yang paling banyak dilakukan oleh organisasi, karena memang sangat terkait dengan penilaian kinerja berbasis indikator atau parameter keberhasilan yang telah ditetapkan pada tahapan perencanaan. Evaluasi 
hasil juga sangat ditunggu dalam tahapan pembangunan berikutnya, yaitu dalam perbaikan perencanaan.

- Hasil temuan evaluasi Renja Bappeda menunjukan bahwa tingkat capaian indikator kinerja dan indikator anggaran relatif masih kurang baik. Artinya Bappeda, masih perlu untuk melakukan upaya cukup keras dalam perbaikan komitmen perencanaan hingga evaluasi, agar apa yang telah direncanakan dalam Renstra ataupun Renja, dapat dilaksanakan dengan konsisten hingga tahapan akhir pelaksanaan program dan kegiatan.

\section{Faktor Penentu Pengembangan Evaluasi Renja.}

Bagian ini akan memberikan beberapa usulan strategis bagi pengembangan evaluasi perencanaan yang lebih bersahabat sehingga dapat dijalankan dengan lebih baik oleh setiap organisasi.

Penegasan Komitmen. Salah satu persoalan yang dihadapi dalam bidang perencanaan adalah ketidakmampuan untuk mengawal apa yang sudah direncanakan hingga tahapan realisasi berakhir, apalagi mengawalnya dalam kurun waktu yang cukup lama (jangka menengah dan jangka panjang). Dalam kehidupan berpemerintahan di daerah, faktor kesamaan persepsi antar pihak ternyata menjadi awal dari perubahan dan perbaikan tersebut. Komitmen harus dibangun dengan lebih kuat diantara berbagai pemegang kekuasaan ataupun diantara semua stakeholders pembangunan, baik internal maupun eksternal pemerintah daerah. Komitmen bisa dibangun dengan cara membiasakan untuk melakukan koordinasi dan komunikasi terkait dengan permasalahan dan isu strategis bersama (daerah atau organisasi). Eksekutif dengan Legislatif bisa mengawali dan memberi contoh penegakan komitmen pengawal dokumen perencanaan yang telah ditetapkan "harus" dapat terealisasikan dengan baik hingga akhir tahun atau masa perencanaannya, contoh baik ini akan membuat jajaran SKPD dan berbagai kelompok yang terlibat dalam perencanaan pembangunan ikut berpikir dan bertindak yang sama pada semua level perencanaan, pelaksanaan, dan evaluasi pembangunan. Komitmen akan menciptakan keberlanjutan dan ketenangan dalam pelaksanaan pembangunan, daerah akan lebih cepat mencapai tujuan dan sasaran pembangunan sesuai dengan visi dan cita-cita yang diharapkan.

Penetapan Regulasi. Penyusunan evaluasi yang masih setengah hati, termasuk evaluasi Renja oleh SKPD, dapat didukung dengan penetapan regulasi yang mengatur 
pada tingkat Pemkot, mulai dari tahapan persiapan hingga monev Renja. Regulasi ini bisa juga digabungkan untuk pengaturan dokumen perencanaan yang lain. Melalui pengaturan ini, diharapkan akan lebih jelas langkah yang akan diambil oleh setiap SKPD, demikian pula akan memudahkan Bappeda sebagai pemangku kewenangan perencanaan pembangunan dalam mengawal keharusan setiap SKPD melakukan evaluasi Renja. Bila ini telah ada maka kalender evaluasi Renja akan menjadi prioritas bagi SKPD, dan hasil evaluasi akan dapat bermanfaat bagi penyusunan perencanan pada tahapan berikutnya.

Dukungan Sumber Daya. Pada masa sekarang ini, setiap pelaksanaan tugas pemerintahan membutuhkan dukungan teknologi informasi dan komunikasi, selaras dengan upaya pengembangan e-office menuju e-Government. Perencanaan pembangunanpun tidak terlepas dari keharusan pemutakhiran teknologi informasi dan komunikasi tersebut.Selama ini Bappeda sudah memiliki sistem dalam pelaksanaan fungsi perencanaan yang diampu, yaitu SIMPERDA (Sistem Perencanaan Pembangunan Daerah). Pelaksanaan SIMPERDA masih memiliki cukup banyak kelemahan yang harus segera ditangani, antara lain: keterbatasan dalam daya kapasitas, keterbatasan dalam integrasi lintas sistem (misalnya dengan sistem yang dibuat instansi/SKPD lain), adanya keterbatasan dalam sumber daya manusia yang menangani, baik sisi jumlah maupun keahlian.

\section{PENUTUP}

\section{Kesimpulan.}

Beberapa kesimpulan dapat dirumuskan berdasarkan pada hasil dan pembahasan yang telah dilakukan, yaitu sebagai berikut: Pertama. Kondisi evaluasi Renja Bappeda masih belum optimal, hanya melakukan evaluasi Renja pada tahapan hasil, sedangkan yang tahapan kebijakan dan pelaksanaan belum dilakukan, dengan beberapa catatan pokok sebagai berikut: (a) Evaluasi Kebijakan, bila dilihat dari hasil penelitian sebenarnya sebagian pameternya sudah dipenuh/ dijalankan, seperti: pembentukan tim, analisis kinerja pelayanan, evaluasi Renja tahun sebelumnya; namun ada pula yang masih kurang optimal, seperti: pengolahan data dan informasi belum upto date, perumusan isu strategis, tujuan, sasaran, hingga prioritas kurang berdasarkan pada hasil evaluasi, kesulitas mengawal pagu anggaran, dan kekurangtertiban dalam administrasi legalitas dokumen Renja; (b) Evaluasi Pelaksanaan, dari hasil penelitian ditemukan 
masih ada ketidakselarasan antara Renstra dengan Renja, ataupun target Renja dengan realisasi Renja; dan (c) Evaluasi Hasil, dari hasil penelitian ditemukan bahwa hasil Renja masih rendah, baik dari sisi kinerja maupun dari sisi anggaran. Kedua. Beberapa permasalahan atau kendala utama ditemukan dalam pelaksanaan evaluasi Renja Bappeda, yaitu: (a) lemahnya komitmen stakeholder akan pentingnya evaluasi Renja; (b) ketiadaan dasar regulasi internal pemkot yang mewajibkan melakukan evaluasi Renja; (c) belum maksimalnya dukungan teknologi informasi perencanaan; (d) keterbatasan jumlah dan kualitas sumber daya manusia perencana; dan (e) kurang tertibnya aspek administrasi tentang legalitas dokumen Renja, dan lain-lain.

\section{Saran}

Berdasarkan pada kesimpulan, dirumuskan beberapa rekomendasi perbaikan evaluasi Renja sebagai berikut:Pertama. Evaluasi kebijakan dapat diperbaiki dengan melakukan beberapa hal, seperti: penataan SIMPERDA dengan penambahan daya kapasitas dan kemampuan integrasi lintas sistem; pemanfaatan hasil evaluasi kinerja pelayanan dan Renja tahun sebelumnya sebagai dasar penentuan masalah dan isu strategis organisasi; kepatuhan pada pengawalan dokumen payung (yang lebih atas), dalam hal ini Renja harus patuh pada Renstra, misalnya dalam alokasi anggaran; penetapan regulasi yang mengatur kewajiban membuat evaluasi Renja, termasuk aspek legalitas dokumen Renja.Kedua. Evaluasi Pelaksanaan dapat diperbaiki dengan melakukan beberapa hal sebagai berikut:pengembangan komitmen antar pelaku pembangunan, terutama dalam menjaga keselarasan antar dokumen; peningkatan koordinasi, komunikasi dan pembinaan SKPD oleh Bappeda terkait dengan perencanaan pembangunan. Ketiga. Evaluasi Hasil dapat diperbaiki dengan melakukan beberapa hal sebagai berikut: penetapan indikator kinerja dan anggaran yang konsisten dengan dokumen payungnya; peningkatan efektivitas pemantauan triwulan; prioritas hasil kinerja program kegiatan yang rendah untuk diberbaiki pada tahapan perencanan berikutnya.Keempat. Beberapa saran lain dapat diberikan, seperti: peningkatan insentif bagi tenaga perencana pada setiap SKPD; pengadaan tenaga fungsional perencana di Bappeda. 


\section{DAFTAR PUSTAKA}

Donald M. Norris and Nick L. Poulton. (2010). A Guide to Planning for Change. Michigan: The Society for College and University Planning (SCUP).

Alan Walter Steiss. (2003). Strategic Management for Public and Nonprofit Organizations. New York: Marcel Dekker, Inc.

Marios I. Katsioloudes. (2006). Strategic Management: Global Cultural Perspectives for Profit and Non-Profit Organizations. San Francisco: Elsevier Butterworth Heinemann Publications.

Franco Archibugi. (2008). Planning Theory: From the Political Debate to theMethodological Reconstruction. Roma: Springer-Verlag.

John M. Bryson. (2004). Strategic Planning For Public And Nonprofit Organizations: A Guide To Strengthening And Sustaining Organizational Achievement. San Francisco: John Wiley \& Sons, Inc.

Undang-Undang Nomor 25 Tahun 2004 Tentang Sistem Perencanaan Pembangunan Nasional.

Peraturan Pemerintah Nomor 8 Tahun 2008 Tentang Tahapan, Tata Cara Penyusunan, Pengendalian Dan Evaluasi Pelaksanaan Rencana Pembangunan Daerah.

Peraturan Menteri Dalam Negeri Nomor 54 Tahun 2010 tentang Pelaksanaan Peraturan Pemerintah Nomor 8 Tahun 2008 Tentang Tahapan, Tatacara Penyusunan, Pengendalian, dan Evaluasi Pelaksanaan Rencana Pembangunan Daerah. 